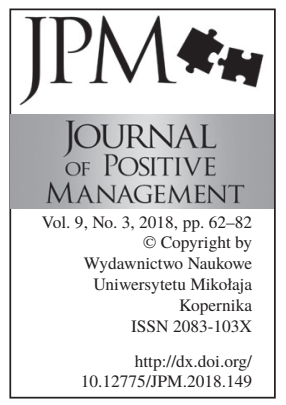

\title{
LOGISTICS SUPPORT OF CSR ACTIVITIES \\ IN THE GLOBAL SUPPLY CHAINS OF THE PHARMACEUTICAL SECTOR
}

\author{
Katarzyna Osiecka-Brzeska ${ }^{\mathrm{a}}$, Agnieszka Szmelter-Jarosz ${ }^{\mathrm{b}}$ \\ anniversity of Business and Administration in Gdynia

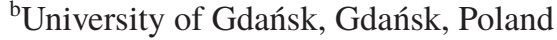 \\ e-mail: kat.osiecka@wp.pl \\ e-mail: a.szmelter@ug.edu.pl
}

\begin{abstract}
Purpose: Research paper identifies the current trends in the logistics support of the global pharmaceutical industry, including CSR activities. Research results can be a good reference point for decision-makers in the fields of logistics management. The subject matter of the paper is based mainly on the comparison of logistics practices in the area of CSR in the pharmaceutical industry supply chains.
\end{abstract}

Methodology: To achieve the research goal stated for this study, two research procedures were chosen and implemented:1) documents review (triangulation of sources); 2) literature review with the use of Boolean logic and the chosen procedure, valid for socio-economic research.

Findings: This paper points out that the set of methods and tools used in logistics support of the CSR activities overlap in some part the set of methods and tools for core business activity (commercial sales of medicines).

Implications for practice: Research results can be a good reference point for decision-makers in the fields of logistics management and CSR of the pharmaceutical industry.

Originality/value: This paper is the first about logistics support of CSR activities in the pharmaceutical industry. It shows the similarities and differences between the support of the basic, primary activities and CSR ones. It can be the basis for further theoretical and empirical research.

Keywords: CSR, pharmaceutical industry, logistics, logistics service

Paper type: Conceptual paper 


\section{Introduction}

I would say that the pharmaceutical industry is hyper-competitive from a global perspective. Heather Bresch, CEO of Mylan

The pharmaceutical industry is one of the most innovative sectors worldwide, next to automotive and electronic ones. However, its specifics cause many problems in implementing those innovations, especially because of the strict research, development and launch processes, and very low success ratio in creating new medical products. The legal conditions limit the freedom of actions and make it much more difficult to achieve global success than in other sectors.

Those industry characteristics necessitated the creation of a special action framework for logistics support for both core business and other activities, including corporate social responsibility (CSR). The first of those areas is very well described in the current literature, but there is a lack of papers aimed at presenting the other fields of logistics support. This is very important taking into account that in many companies CSR activities consume little less financial resources, and they cannot be directly translated into revenues and financial performance.

The aim of the article is to identify the methods and tools used in logistics support of the CSR activities in the pharmaceutical industry. The subject matter of the paper is to compare the logistics practices in the area of CSR in the pharmaceutical industry supply chains. Research paper identifies the current trends in the logistics support of the global pharmaceutical industry.

In order to achieve the research goal, two research questions were posed:

RQ1: What methods and tools are used in the logistics service of CSR activities in the pharmaceutical industry?

RQ2: Are these methods and tools different from the basic operations in this industry used in logistics services?

According to the authors' knowledge, currently, there is no study integrating the results of research agencies, scientific literature and company reports on CSR activities and logistical support for these activities. Available sources provide only data that requires further analysis, are based on single cases (especially in the area of mergers and acquisitions) and mainly concern only the development of industry in the emerging countries. Research results can be a good reference point for decision-makers in the fields of logistics management and CSR of the pharmaceutical industry.

The remainder of the paper is organized as follows. First, the specifics of the industry itself and its CSR activities are presented. The next part focuses on the methods used to analyze the data gathered from different sources. The results section explores literature and other sources used to identify the logistics 
LOGISTICS

SUPPORT

OF CSR ACTIVITIES

KatarzynaOsiecka-Brzeska Agnieszka Szmelter-Jarosz support practices in the chosen industry. The next part contains discussion, general conclusion, study's limitations and an indication regarding the future research directions and plans.

\section{Literature review}

\subsection{Pharmaceutical industry}

The global pharmaceutical industry can be divided into three parts. First of them is the (Western) Big Pharma, including established brands from the USA, Europe and Japan and dominating on the global market, developing the new drugs. In addition, in those countries of origin of Big Pharma, the consumption is the highest, has over $40 \%$ of the global market and cover over $80 \%$ of the world's drug consumption (Tempest, 2010). The second entreprises group is built by companies from the emerging economies (China, India and others) called jointly as Pharmerging, focusing mostly on developing the generic drugs, gaining the foreign direct investments and supporting the national industry (Rehman et al., 2015). The companies originally from the rest of the world create the third group. According to the Statista Group, the global consumption value will increase from 887 bln USD in 2010, trough 1135 bln USD in 2016 to 1430 bln USD in 2020 (Statista, 2017) and the global revenues reached now the level of 1,1 trillion USD. The biggest pharmaceutical market is in the USA (about $41-50 \%$ of the global drug consumption), then in China (all Pharmerging countries consume about $20 \%$ of drugs. OECD countries consume over $80 \%$ of the produced drugs (UNODC, 2017). What is more, the Asian countries, like for other sectors, are attractive destinations for locating production sites of Big Pharma companies. The more detailed analysis of the situation of this sector was made by Szmelter (2019).

The specifics of the industry is created mostly by research and development activities. The IFPMA paper reported that developing the new medicine takes $10-15$ years, and there is a very high cost and low success ratio in $R \& D$ in the pharmaceutical area (Shaw and Whitney, 2016). Those problems are compounded by the legal constraints, also secondary patenting - trying to prolong the legal protection for the drug for a longer period of time (Sampat and Shalden, 2017). On the other hand, this causes the problems in generic drugs production and access to medicines by less privileged, poorer societies, especially helpful in treating rare diseases. The world's population has to face the two main problems related to this industry: drug overuse in developed countries and lack or insufficient drug access in the developing ones. Both are addressed by the CSR strategies of pharmaceutical companies.

Both the mentioned groups differ in the length of supply chains, their complexity and tools used in the implementation of basic and logistic processes. Additionally, due to the specifics of the sector, industry-dedicated solutions should 
be implemented in the supply chains (eg in the case of transport of goods sensitive to temperature changes). In most areas, it is also possible to use universal methods and practices popular in other highly innovative industries, such as the IT and automotive industries (eg Build-to-Order production - BTO, lean management).

LOGISTICS

SUPPORT

OF CSR ACTIVITIES

Katarzyna Osiecka-Brzeska Agnieszka Szmelter-Jarosz

\subsection{CSR}

The Corporate Social Responsibility (CSR) has been a subject of many studies and interpretations, therefore the academic literature provides a range of definitions and approaches to the subject. As for the purpose of the article, the authors decided to adopt the three pillars approach, in which the concept of CSR includes economic, social and environmental issues as evenly important pillars of business market actions. The triple bottom line principle proves that environmental and social actions are crucial for the maximization of profit (Elkington, 1998; Dyllick and Hockerts 2002). According to the principle, the joined social, environmental and economic concerns should generate a synergy of profits for the business and its stakeholders. (Steurer, 2005).

The history of Corporate Social Responsibility can be divided into specific eras, classified by the attitude to the concept, what is presented shortly in Figure 1. At the beginning of $20^{\text {th }}$-century, Hadley presented the idea of business trusteeship, in which he reminded that business actions have an influence on the local society and hence business leaders become the managers of the public interest. The concept was developed by both theory and business, what may be confirmed by General Electric idea of business obligations towards a wider range of partner than only stakeholders (France and Bureana, 2015). According to Murphy, the post-war period up to the 1950s was the 'philanthropic' era, during which companies donated to charities more than ever noticed. The next period of the 1960s and 70s may be called an 'Awareness \& Responsibility period. At that time, business became able to recognize its overall responsibility, and involve in community affairs such as urban decay, and racial discrimination. 1970' brought to the corporations the responsibility in business actions, which could be seen in purposeful managerial and organizational actions, which included examining corporate ethics and using social performance disclosures (Murphy, 1978). In the 1980s and 90's the business interest in CSR shifted to alternative or complementary concepts, theories, and models. In response to the political events and policies (such as Rio de Janeiro Summit and Agenda 2000), the business included environmental responsibility into CSR policies. At the same time, the idea of stakeholders developed and was widely implemented to the business actions. As a result, the CSR initiatives included such fields as education, culture and the arts, health and human services, civic and community, international donees, community partners, and NGO partners. Important is the fact that international corporations introduced common standards of CSR actions, and as 
LOGISTICS

SUPPORT

OF CSR ACTIVITIES

KatarzynaOsiecka-Brzeska Agnieszka Szmelter-Jarosz

\begin{tabular}{|c|}
\hline $\begin{array}{c}\text { The Trusteeship } \\
\text { Period }\end{array}$ \\
\hline 1920 , \\
\hline $\begin{array}{l}\text { After era of } \\
\text { industrialization, } \\
\text { the business } \\
\text { started to its } \\
\text { influence on the } \\
\text { society. }\end{array}$ \\
\hline $\begin{array}{c}\text { First attempts of } \\
\text { cooperation with } \\
\text { stakeholders. }\end{array}$ \\
\hline
\end{tabular}

Figure 1.

The historical development of the CSR concept

Source: own preparation. a result, the CSR policies became global. The last period of CSR development was a global outbreak. The idea integrated social, environmental and economic aspects of the business in standardized actions. CSR reached new organizations and gain popularity as a tool of international corporations, SMEs, governments and universities (Carroll, 2008; Moon, 2005).
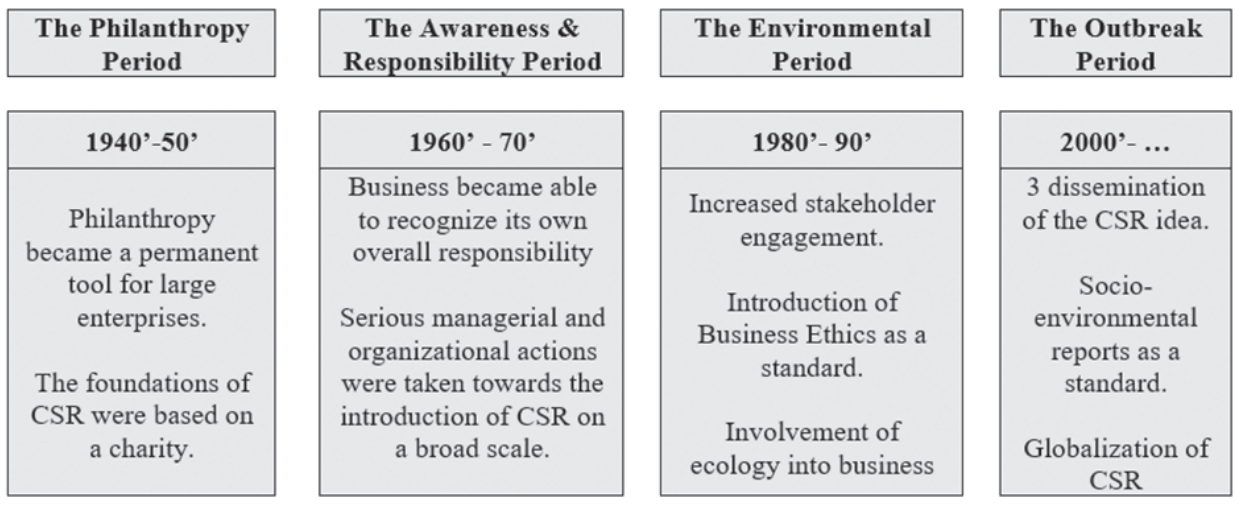

The concept of CSR is connected to the pharmaceutical sector from the very beginning. The first CSR actions towards the health and working and living standards of employees were results of health problems among workers. As the CSR idea developed it touched different aspects of pharmaceutical sector - working conditions, productions standards, business ethics, environmental pollution, etc. still those dimensions were more connected to the economic side of the pharmaceutical industry than to the core meaning of pharmacy. One has to admit that the industry replays to the most crucial problems of the modern world and problems caused by them. This the reason why among the pharma corporations one can find a range of CSR actions directed to the society - from charity actions to social campaigns and training. The pharmaceutical industry is one of the most legally regulated and controlled industries, this may be the reason why the introduction of CSR standards was not problematic in pharma companies. (Leisiger, 2005; Martinuzzi, 2011). Figure 2 shows the global background of CSR in the pharmaceutical industry, as well as examples of CSR tools and action undertaken as the fulfillment of CSR policies.

The role that the pharmaceutical industry fulfills (protection of public health, saving lives, responsibility for public health) obliges it to undertake a number of charitable and social initiatives (donations, social campaigns, prevention health programs) on local and global reach. Therefore, logistics services in supply chains in this industry, also those related to CSR activities, are an important topic in the context of the development of the global economy, especially in most cases related to global supply chains. 
THE MOST SIGNIFICANT PROBLEMS OF THE CONTEMPORARY WORLD

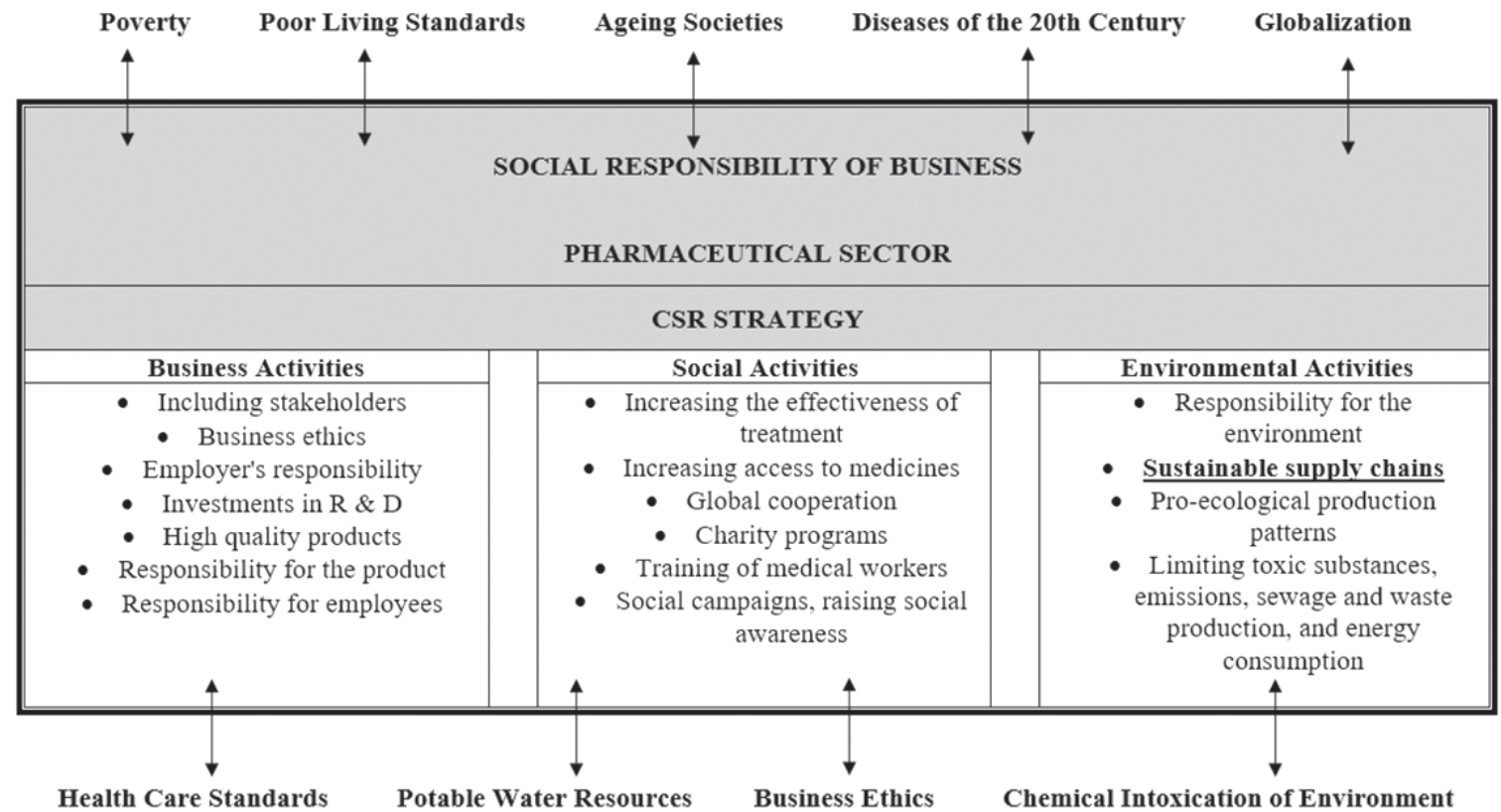

\section{Method}

To achieve the research goal stated for this study, two research procedures were chosen and implemented:

1) documents review, triangulation of sources (OECD database, WHO database, EMIS database, global indices, sustainability reports and CSR reports of companies, others)

2) literature review: a review of the literature with the use of Boolean logic and Denyer, Tranfield, Smart (2003) procedure (modified, see Table 1); analysis of original research papers, case studies and viewpoints with use of the EDS multisource search engine on the EBSCOhost platform.

\begin{tabular}{|c|c|}
\hline Phase & Stage \\
\hline I & 1. Determining the study purpose \\
\hline \multirow{3}{*}{ II } & 1. Determining basic literature (searching in search engines) \\
\hline & 2. Selection of publications for further analysis \\
\hline & 3. Preparing publications database \\
\hline \multirow{2}{*}{ III } & 1. Bibliometric analysis \\
\hline & 2. Content (text) analysis \\
\hline IV & 3. Preparing a report (research results) \\
\hline
\end{tabular}

Figure 2. The background and CSR dimensions in the pharmaceutical sector

Source: own preparation.

Table 1. Research procedure

Source: own preparation. 
LOGISTICS

SUPPORT

OF CSR ACTIVITIES

KatarzynaOsiecka-Brzeska Agnieszka Szmelter-Jarosz

Table 2. The process of literature database creation

Source: own preparation.

* Search rounds: I. using "pharmaceutical"; "CSR" or "corporate social responsibility";

"logistics or

"logistical":

1) $\mathrm{TI} ; \mathrm{AB} ; \mathrm{TX}$,

2) $\mathrm{AB} ; \mathrm{AB} ; \mathrm{AB}$,

3) AB;TI;TX,

4) $\mathrm{AB} ; \mathrm{AB} ; \mathrm{TX}$,

5) $\mathrm{SU} ; \mathrm{AB} ; \mathrm{TX}$;

II. using "pharmaceutical";

"CSR" or

"corporate social responsibility";

"supply chain":

6) TI;AB;TX,

7) $\mathrm{AB} ; \mathrm{AB} ; \mathrm{AB}$,

8) $\mathrm{AB} ; \mathrm{TI} ; \mathrm{TX}$,

9) $\mathrm{AB} ; \mathrm{AB} ; \mathrm{TX}$,

10) $\mathrm{SU} ; \mathrm{AB} ; \mathrm{TX}$.
There were the obstacles in the implementation of the second procedure because of the lack of literature sources strictly related to logistics support or logistics activities in the pharmaceutical industry. This resulted in the need to search for sources of literature in 10 rounds (see Table 2). Finally, 38 from 103 identified sources were included in the literature review.

\begin{tabular}{lcccccccccc}
\hline \multirow{2}{*}{ Search criteria } & \multicolumn{10}{c}{ Search round no.* } \\
\cline { 2 - 11 } & 1 & 2 & 3 & 4 & 5 & 6 & 7 & 8 & 9 & 10 \\
\hline No. of literature sources & 1 & 3 & 5 & 14 & 3 & 18 & 15 & 15 & 45 & 18 \\
\hline After removing duplicates & \multicolumn{11}{c}{103} \\
\hline After abstracts verification & \multicolumn{11}{c}{54} \\
\hline After text analysis & \multicolumn{11}{c}{38} \\
\hline
\end{tabular}

\section{Results}

\subsection{Different (non-scientific) sources}

The characteristics of enterprises from Big Pharma and Pharmerging differ mainly in the size of CSR activities (Big Pharma countries are more involved in these activities, also only they are listed in global summaries, e.g. Change the World 2017, The Access to Medicine Index, Dow Jones Sustainability Index, see Appendix 1). Also, companies representing Big Pharma use a wider range of logistics practices in their business. Those are: complexity management (in supply chains), lean management, Build-to-Stock (or Make-to-Stock) activities, differentiation of distribution channels for different kinds of customers (commercial, government, NGOs, own foundations), cold chain management, special Customer Relationship Management practices and systems for NGOs and others, information logistics, using $4^{\text {th }}$ Party Logistics (orchestrator) services in many distribution channels.

The companies well-known for their CSR activities (so in this regard - also the best logistics practices) are (in order of appearance in particular global CSR-related indices): Johnson\&Johnson (USA), Merck (USA), Roche Holding (Switzerland), AstraZeneca (UK), Novartis (Switzerland), Sanofi (France), Takeda Pharmaceutica (Japan), Biogen (USA), Bristol-Myers Squibb (USA), Daiichi Sankyo (Japan), Eli Lilly (USA), GlaxoSmithKline (UK), Novo Nordisk (Denmark), Pfizer (USA).

One of the subsequent topics in the pharmaceutical industry is a trend of outsourcing medical research in the process of drug development. This relocation of the industrial production to the Asian countries has an impact on the 
environment, so additional CSR actions should be planned and provided to avoid the negative impact or overuse.

The most-often implemented CSR practices in this industry, for which the logistics support was crucial to be created and practised, also in the information logistics area, are health prevention and treatment programs (eg. for children, pregnant mothers), programs run by foundations, subsidiaries of pharmaceutical concerns and non-governmental organizations, donations, public-private partnership, price differentiation, special licensing for resource-poor countries, increasing product distribution capacity, supply chain support, mHealth initiatives, healthcare campaigns, employee placement programs and targeted research and development.

\subsection{Literature sources}

Firstly, at the end of the $90 \mathrm{~s}$ of the $20^{\text {th }}$ century, the sustainability strategies were those of the most interests in the pharmaceutical sector. Over time, sustainability practices were shifted into CSR ones (Schneider et al., 2010). The CSR programs, mentioned mainly in the literature as the case studies for the single companies (Pfizer, Eisai Pharma, Takeda) include the cooperation with NGOs and governments and need to have ready-to-use pricing procedures and distribution channels (Vian et al., 2007; Graya et al., 2011; Witty, 2011; Thorsteinsdóttir et al., 2017). They are a part of the general strategy of the pharmaceutical company and in most cases, have their own functional strategy (CSR strategy) built into the company culture (Smith, 2008), what makes this industry the most leading in CSR practices (Schneider et al., 2010; Toma and Marinescu, 2012). They are also a part of PPP initiatives in CSR (Sturchio, 2008). However, US-origin CSR context and EU-origin CSR context are still different (EU context is more strict), but they tend to each other (van de Pol and de Bakker, 2010). Definitely, CSR practices should be mandatory for all companies (Azim and Azam, 2013; Givel, 2013; Khan et al., 2015; Droppert and Bennet, 2015; Mehralian et al., 2016) and oriented for the long term (Alexandra and Fort, 2014), regardless the region (Rehman et al., 2015; aus der Beck et al., 2016), company size (Min et al., 2017) and the evolutionary CSR stage of the company (O'Riordan and Fairbrass, 2014; Khaleel, 2017; Lau et al., 2018). Mandatory procedures and practices should be stated by international organizations (Shaw and Whitney, 2016).

One of the most important logistics problems is to give the access to medicines in poor countries (Grover et al., 2012), countries with insufficient law (Adobor, 2012) and those with the problem of military conflicts. The procedures are enhanced by providing safety to people helping the most dangerous regions and special ones dedicated to medical food and drugs needed to be stored and transported in special temperature. Those are practices related to the area of humanitarian logistics and military logistics (Greeve, 2008) and requires 
complexity management and cold chain management skills (Enyinda et al., 2009; Bishara, 2006) both in a single organization and in the whole supply chain (primary and CSR). Logistics support in CSR activities should be more focused on the emerging economies (Friemann and Schönsleben, 2013, Göpfert et al., 2013).

New financing and pricing models and international commitments (for example the Advanced Market Commitment), including tax exemptions and brakes encourage the private sector to invest in research and development (Witty, 2011). Such cooperation is focused on, among others, joint basic research, enhancing the access to medicines, transferring the technology (Szmelter, 2019). Those kinds of operations need special planning and control procedures. It needs the support of the primary processes, so logistics problems solving (transportation, distribution, planning the operations, sourcing, needs analysis etc.), therefore the mathematical and IT solutions are needed to address specific needs of this part of the market (Sturchio, 2008). Pharmaceutical supply chains are complex. There are many uncontrolled variables in the process of supply chain planning (Sousa et al., 2011; Susarla and Karimi, 2012; Mousazadeh et al., 2015). Friemann and Schönsleben (2013) stated that pharmaceutical logistics should be benchmarked to some extent on the automotive industry. Those are hiring 4PL, lean management, VMI, collaboration with suppliers and data transparency (Friemann and Schönsleben, 2013).

An essential part of the supply chain management in this sector is cold chain management for temperature-sensitive pharmaceuticals. It requires a longer time for planning and execution and also because of the more volatile demand.

Therefore, the logistics practices identified for the CSR strategy are to some extent, the same for the core and CSR activities (see Figure 3) and also focused on the optimization of flows (Sousa et al., 2011), multi-period, multi-site, multiechelon planning (Susarla and Karimi, 2012; Mousazadeh et al., 2015) and multi-criteria supply chain risk management (Teker, 2017). For the primary, core business and CSR activities, the shift from traditional, Make-to-Stock strategy, to Make-to-Order strategy is visible (Harrington et al., 2017).

Among the concepts, methods and tools used in logistics service in the chosen industry, common for core and CSR activities are 4PL outsourcing, cold chain management, lean management, advanced planning and forecasting, strict cooperation with suppliers and Make-to-Order production. The methods and concepts specific for the CSR activities are enhanced information logistics, dedicated CRM systems, humanitarian and military logistics, separate procurement and distribution channels with special pricing procedures.

The CSR reciprocity is the joint occurrence of the CSR strength of buyers and sellers. CSR reciprocity between buyer and seller firms in a supply chain affects channel tie intensity and channel sales performance (main effects) and that market 


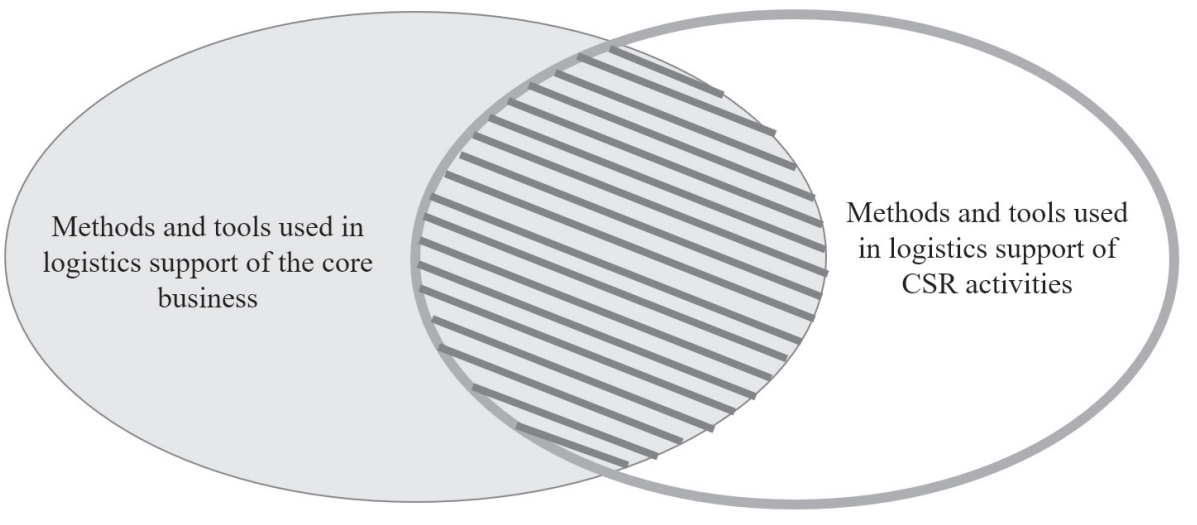

competition may amplify these influences (moderated effects). CSR reciprocity positively influences channel relationship performance. CSR has no significant influence on channel relationship performance when either buyers or sellers do not exhibit high CSR strength. The positive effect of CSR reciprocity on channel relationship performance is enhanced when the market competition is high rather than low (Luo and Zheng, 2013).

\section{Conclusion}

This research showed the characteristics of the logistics support of CSR activities. This is the first summary in the literature about this area of logistics activities. It extends current literature by summarising available literature and other sources on the CSR logistics and results from different research approaches, procedures, samples and countries. The research procedure made it possible to address the research questions. The answer for both ones is that the set of methods and tools used to support CSR activities in the pharmaceutical industry partly overlaps with the set used in the core business and contains, for example, lean management, cold chain management, etc. Nevertheless, there is a group of methods and tools dedicated exclusively to CSR operations.

This research has a few limitations. It is, to some extent, based on the current literature, but the search criteria were restricted. In such a research procedure, there is always a risk of omitting the important literature positions. The similar situation applies to other analyzed sources. On the other hand, there was a lack of literature strictly related to the topic of logistics in CSR activity in the pharmaceutical industry.

Despite these limitations, the described research results are promising and provide many future research possibilities, also can serve as a basis for further theoretical and empirical studies. Future research should be conducted to obtain
LOGISTICS SUPPORT OF CSR ACTIVITIES

Katarzyna Osiecka-Brzeska Agnieszka Szmelter-Jarosz

Figure 3. The relations between logistics practices used in core business and CSR activities in the pharmaceutical industry

Source: own preparation. 
LOGISTICS

SUPPORT

OF CSR ACTIVITIES

KatarzynaOsiecka-Brzeska Agnieszka Szmelter-Jarosz more data on logistics in the CSR activities of pharmaceutical companies. The authors hope that these and many other issues in the discusses area will be addressed by other researchers.

\section{References}

Adobor, H. (2012), "Ethical Issues in Outsourcing: The Case of Contract Medical Research and the Global Pharmaceutical Industry", Journal of Business Ethics, Vol. 105 No. 2, pp. 239-255.

Alexandra Countess of Frederiksborg, Fort, T.L. (2014), “The paradox of pharmaceutical CSR: The sincerity nexus”, Business Horizons, Vol. 57, pp. 151-160.

Azim, M.I., Azam, S. (2013), Corporate Sustainability Reporting by Pharmaceutical Companies: is it what it seems to be?", Corporate Ownership \& Control, Vol. 11 No. 1, pp. 754-765.

aus der Beek, T., Weber, F. A., Bergmann, A., Hickmann, S., Ebert, I., Hein, A., Küster, A. (2016), „Pharmaceuticals in the environment - Global occurrences and perspectives”, Environmental Toxicology and Chemistry, Vol. 35 No. 4, pp. 823-835.

Carroll, A.B. (2008), "A history of corporate social responsibility. Concepts and practices." in: Crane, A., Matten, D., McWillams, A., Siegel, D.S. (Eds.) The Oxford Handbook of Corporate Social Responsibility, Oxford, UK, pp. 34-42.

Droppert, H., Bennett, S. (2015), "Corporate social responsibility in global health: an exploratory study of multinational pharmaceutical firms", Globalization and Health, Vol. 11 No. 15, pp. 1-8.

Dyllick, T., Hockerts, K. (2002), "Beyond the business case for corporate sustainability", Business Strategy and the Environment, Vol. 11 No. 2, pp. 130-141.

"Eisai Pharma gets award for CSR activity" (2014), Chemical Business, January, p. 57.

Elkington, J. (1998), "Partnership from cannibals with forks: The triple bottom line of

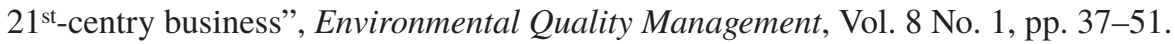

Enyinda, I.C., Briggs, C., Bachkar, K. (2009), "Managing risk in pharmaceutical global supply chain outsourcing: applying Analytic Hierarchy Process model", American Society of Business and Behavioral Sciences Las Vegas, Vol. 16 No. 1, pp. 1-15.

France, N., Bureana, E. (2015), "History of Corporate Social Responsibility Concept". Annales Universitatis Apulensis Series Oeconomica, Vol. 17 No. 2, pp. 30-36.

Friemann, F., Schönsleben, P. (2013), “Global Logistics Excellence and Best Practices in Pharma: Results from an interview series with 11 large, multinational pharmaceutical companies", available at: https://www.research-collection.ethz.ch/, pp. 1-48 (accessed 10 January 2019).

Givel, M. (2013), "Modern Neoliberal Philanthropy: motivations and impact of Pfizer Pharmaceutical's corporate social responsibility campaign", Third World Quarterly, Vol. 34 No. 1, pp. 171-182.

Göpfert, I., Stephan, M., Wellbrock, W., Ackermann, M. (2013), “An Empirical Analysis of the Board Composition Concerning Logistics Competencies", World Academy of Science, Engineering and Technology International Journal of Mechanical and Industrial Engineering, Vol. 7 No. 3, pp. 602-608. 
Evidence from the pharmaceutical industry", Journal of Operations Management, Vol. 29 No. 7, pp. 737-752.

Greve, J. (2008), "Healthcare in developing countries and the role of business: a global governance framework to enhance the accountability of pharmaceutical companies", Corporate Governance: The International Journal of Business in Society, Vol. 8 No. 4, pp. 490-505.

Grover, A., Citro, B., Mankad, M., Lander, F. (2012), "Pharmaceutical companies and global lack of access to medicines: strengthening accountability under the right to health", Journal of Law Medicine and Ethics, Vol. 40 No. 2, pp. 234-250.

Harrington, T.S., Phillips, M.A., Singh Srai, J. (2017), "Reconfiguring global pharmaceutical value networks through targeted technology interventions", International Journal of Production Research, Vol. 55 No. 5, pp. 1471-1487.

Khaleel, M., Chelliah, S., Rauf, S., Jamil, M. (2017), "Impact of perceived corporate social responsibility on attitudes and behaviors of pharmacists working in MNCs", Humanomics, Vol. 33 No. 4, pp. 453-469.

Khan, Z., Lew, Y.K., Park, B.I. (2015), "Institutional legitimacy and norms-based CSR marketing practices: Insights from MNCs operating in a developing economy", International Marketing Review, Vol. 32 No. 5, pp. 463-491.

Lau, A.K.W., Lee P.K.C., Cheng, T.C.E. (2018), "An empirical taxonomy of corporate social responsibility in China's manufacturing industries", Journal of Cleaner Production, Vol. 188, pp. 322-338.

Lee, P.K.C., Lau, A.K.W., Cheng, T.C.E., "Employee rights protection and financial performance", Journal of Business Research, Vol. 66 No. 10, pp. 1861-1869.

Leisinger, K.M. (2005), "The Corporate Social Responsibility of the Pharmaceutical Industry: Idealism without Illusion and Realism without Resignation", Business Ethics Quarterly, Vol. 15 No. 4, pp. 579-592.

Luo, X., Zheng, Q. (2013), "Reciprocity in Corporate Social Responsibility and Channel Performance: Do Birds of a Feather Flock Together?", Journal of Business Ethics, Vol. 118 No. 1, pp. 203-213.

Martinuzzi, A., Krumay, B., Pisano, U. (2011), "Focus CSR: The New Communication of the EU Commission on CSR and National CSR Strategies and Action Plans", European Sustainable Development Network, available at: https://www.researchgate.net/ publication/267801215_Focus_CSR_The_New_Communication_of_the_EU_Commission_on_CSR_and_National_CSR_Strategies_and_Action_Plans (accessed 10 January 2019).

Matten, D., Moon, J. (2005), “A Conceptual Framework for Understanding CSR”, in: Habisch, A., Jonker, J., Wegner, M., Schmidtpeter, R. (Eds.), Corporate Social Responsibility Across Europe, Springer Berlin, Heidelberg.

Mehralian, G., Nazari, J.A., Zarei, L., Rasekh, H.R. (2016), “The effects of corporate social responsibility on organizational performance in the Iranian pharmaceutical industry: The mediating role of TQM", Journal of Cleaner Production, Vol. 135, pp. 689-698.

Min, M., Desmoulins-Lebeault, F., Esposito, M. (2017), "Should pharmaceutical companies engage in corporate social responsibility?", Journal of Management Development, Vol. 36 No. 1, pp. 58-70. 
LOGISTICS

SUPPORT

OF CSR ACTIVITIES

Katarzyna Osiecka-Brzeska Agnieszka Szmelter-Jarosz
Mousazadeh, M., Torabi, S.A., Zahiri, B. (2015), "A robust possibilistic programming approach for pharmaceutical supply chain network design”, Computers and Chemical Engineering, Vol. 82, pp. 115-128.

Murphy, P.E. (1978), "An Evolution: Corporate Social Responsiveness", University of Michigan Business Review, November.

O’Riordan, L., Fairbrass, J. (2014), "Managing CSR Stakeholder Engagement: A New Conceptual Framework", Journal of Business Ethics, Vol. 125, pp. 121-145.

OECDC (2017), “World Drug Report 2017”, available at: https://www.unodc.org/ wdr2017/index.html (accessed 14 January 2019).

Rehman, M.S.U., Rashid, N., Ashfaq, M., Saif, A., Ahmad, N., Han, J.-I. (2015), “Global risk of pharmaceutical contamination from highly populated developing countries", Chemosphere, Vol. 138, pp. 1045-1055.

Shaw, B., Whitney, P. (2016), "Ethics and compliance in global pharmaceutical industry marketing and promotion: The role of the IFPMA and self-regulation", Pharmaceuticals Policy and Law, Vol. 18, pp. 199-206.

Smith, A.D. (2008), "Corporate social responsibility practices in the pharmaceutical industry", Business Strategy Series, Vol. 9 No. 6, pp. 306-315.

Sousa, R.T., Liu, S., Papageorgiou, L.G., Shah, N. (2011), "Global supply chain planning for pharmaceuticals", Chemical Engineering Research and Design, Vol. 89, pp. 2396-2409.

Statista (2017), "Medicine Spending Worldwide", available at: https://www.statista.com/ statistics/280572/medicine-spending-worldwide/ (accessed 28 January 2019).

Steurer, R., Langer, M.E., Konrad, A., Martinuzzi, A. (2005), “Corporations, stakeholders and sustainable development I: a theoretical exploration of business society relations", Journal of Business Ethics, Vol. 61 No. 3, pp. 263-281.

Sturchio, J.L. (2008), "Business engagement in public programs: the pharmaceutical industry's contribution to public health and the millennium development goals", Corporate Governance: The International Journal of Business in Society, Vol. 8 No. 4, pp. 482-489.

Susarla, N., Karimi, I.A. (2012), "Integrated supply chain planning for multinational pharmaceutical enterprises", Computers and Chemical Engineering, Vol. 42, pp. 168-177.

Szmelter, A. (2019), "Global Pharmaceutical Industry: Characteristics and Trends", in: Nozari, H., Szmelter, A. (Eds.), Global Supply Chains in the Pharmaceutical Industry, IGI Global, Hershey, Pennsylvania, USA, pp. 57-85.

Teker, S.C. (2017), “The Implementation of Analytic Hierarchy Process in Pharmaceutical Industry for Selection Process of $3^{\text {rd }}$ Party Logistics Service Provider", Öneri, Vol. 12 No. 48, pp. 107-124.

Tempest, B. (2010), "A structural change in the global pharmaceutical marketplace", Journal of Generic Medicines, Vol. 7 No. 2, pp. 113-117.

Thorsteinsdóttir, H., Ovtcharenko, N., Kohler, J.C. (2017), “Corporate social responsibility to improve access to medicines: the case of Brazil", Globalization and Health, Vol. 13 No. 10, pp. 1-11.

Toma, S.-G., Marinescu, P. (2012), "Business Models Based on Corporate Social Responsibility: the Case of Global Pharmaceutical Companies", Ovidius University Annals. 
Tranfield, D., Denyer, D., Smart, P. (2003), "A systematic review of literature on offshoring of value chain activities", British Journal of Management, Vol. 14 No. 3, pp. 207-222.

Valverde J.-L. (2012), “Corporate responsibility and pharmaceutical fraud”, Pharmaceuticals Policy and Law, Vol. 14, pp. 129-156.

Vian, T., McCoy, K., Richards, S.C., Connelly, P., Feeley, F. (2007), “Corporate Social Responsibility in Global Health: The Pfizer Global Health Fellows International Volunteering Program", Human Resource Planning, Vol. 30.1, pp. 30-35.

Witty, A. (2011), "New Strategies For Innovation In Global Health: A Pharmaceutical Industry Perspective”, Health Affairs, Vol. 30 No. 1, pp. 118-126.

\section{Appendix 1. Sources review results}

\begin{tabular}{|c|c|c|c|c|c|c|c|c|c|c|c|}
\hline Index & & 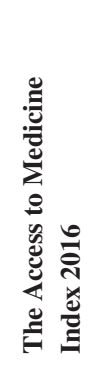 & 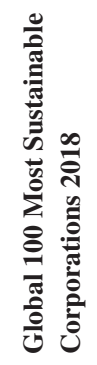 & 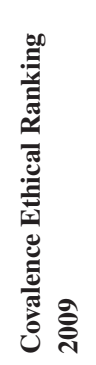 & 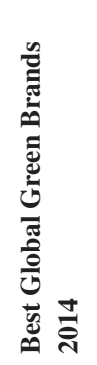 & 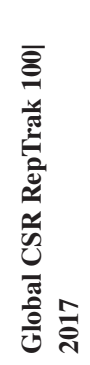 & 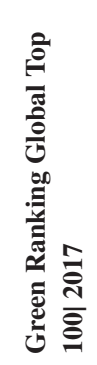 & 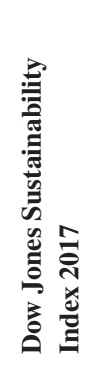 & 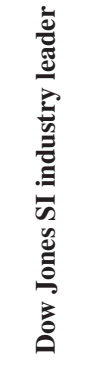 & 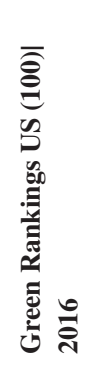 & 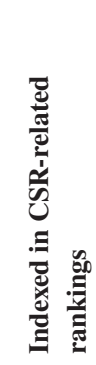 \\
\hline Company name & Country & Rank & Rank & Rank & Rank & Rank & Rank & Status & Status & Rank & \\
\hline Abbott Laboratories & United States & & & $\# 5$ & & & & G & & & $22.22 \%$ \\
\hline AbbVie & United States & $\# 9$ & & & & & & G & & & $22.22 \%$ \\
\hline Aetna & United States & & & $\# 12$ & & & & & & $\# 64$ & $22.22 \%$ \\
\hline Allergan & Ireland & & $\# 20$ & & & & & & & $\# 13$ & $22.22 \%$ \\
\hline Amgen & United States & & & $\# 25$ & & & & & & $\# 49$ & $22.22 \%$ \\
\hline Astellas Pharma & Japan & $\# 20$ & & $\# 28$ & & & & & & & $22.22 \%$ \\
\hline AstraZeneca & United Kingdom & $\# 7$ & $\# 34$ & $\# 8$ & & & & $\mathrm{~S}$ & & & $44.44 \%$ \\
\hline Baxter International & United States & & & $\# 11$ & & & & - & & & $22.22 \%$ \\
\hline Bayer & Germany & $\# 12$ & & & & & & $\mathrm{~S}$ & & & $22.22 \%$ \\
\hline Beckton-Dickinson & United States & & & $\# 16$ & & & & & & & $11.11 \%$ \\
\hline Biogen & United States & & & & & & & $\mathrm{S}, \mathrm{IM}$ & YES & $\# 5$ & $33.33 \%$ \\
\hline Boehringer Ingelheim & Germany & $\# 16$ & & $\# 6$ & & & & & & & $22.22 \%$ \\
\hline Boston Scientific & United States & & & $\# 24$ & & & & & & & $11.11 \%$ \\
\hline Bristol-Myers Squibb & United States & $\# 13$ & & $\# 2$ & & & & - & & & $33.33 \%$ \\
\hline Cardinal Health & United States & & & & & & & $\mathrm{IM}$ & & $\# 76$ & $22.22 \%$ \\
\hline Celgene & United States & & & & & & & & & $\# 54$ & $11.11 \%$ \\
\hline CIGNA Group & United States & & & $\# 22$ & & & & G & & & $22.22 \%$ \\
\hline
\end{tabular}




\begin{tabular}{|c|c|c|c|c|c|c|c|c|c|c|c|}
\hline Index & & 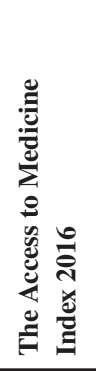 & 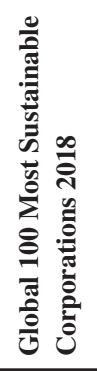 & 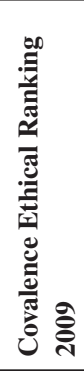 & 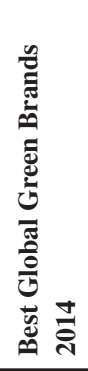 & 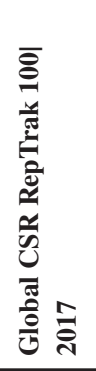 & 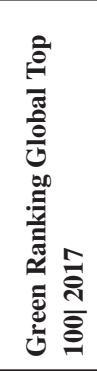 & 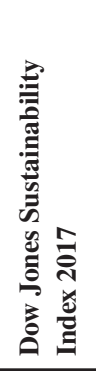 & 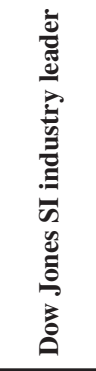 & 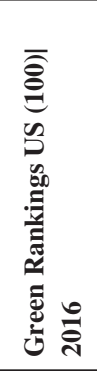 & 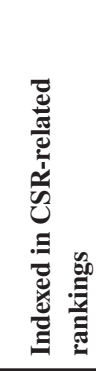 \\
\hline Company name & Country & Rank & Rank & Rank & Rank & Rank & Rank & Status & Status & Rank & \\
\hline Daiichi Sankyo & Japan & $\# 18$ & & $\# 19$ & & & & $\mathrm{~S}$ & & & $33.33 \%$ \\
\hline Eisai & Japan & $\# 11$ & & & & & & - & & & $22.22 \%$ \\
\hline Eli Lilly & United States & $\# 17$ & $\# 37$ & $\# 13$ & & & & & & & $33.33 \%$ \\
\hline Genentech & United States & & & $\# 23$ & & & & & & & $11.11 \%$ \\
\hline Gilead Sciences & United States & $\# 8$ & & & & & & & & & $11.11 \%$ \\
\hline GlaxoSmithKline & United Kingdom & $\# 1$ & $\# 53$ & $\# 1$ & & & & G & & & $44.44 \%$ \\
\hline Johnson\&Johnson & United States & $\# 2$ & $\# 92$ & $\# 7$ & $\# 12$ & $\# 34$ & $\# 22$ & & & $\# 11$ & $77.78 \%$ \\
\hline Medco Health Solutions & United States & & & $\# 21$ & & & & & & & $11.11 \%$ \\
\hline Medtronic & Ireland & & & $\# 26$ & & & & IM & & & $22.22 \%$ \\
\hline Merck & United States & $\# 5$ & $\# 13$ & $\# 17$ & & & $\# 33$ & & & $\# 82$ & $55.56 \%$ \\
\hline Merck & Germany & $\# 4$ & & & & & & & & & $11.11 \%$ \\
\hline Novartis & Switzerland & $\# 3$ & $\# 64$ & $\# 3$ & & & & $\mathrm{~S}$ & & & $44.44 \%$ \\
\hline Novo Nordisk & Denmark & $\# 10$ & & $\# 9$ & & & & B & & & $33.33 \%$ \\
\hline Pfizer & United States & $\# 14$ & & $\# 15$ & & & & & & $\# 57$ & $33.33 \%$ \\
\hline Roche Holding & Switzerland & $\# 19$ & & $\# 4$ & & & $\# 14$ & G & YES & & $55.56 \%$ \\
\hline Sanofi & France & $\# 6$ & $\# 22$ & $\# 14$ & & & & $\mathrm{~B}$ & & & $44.44 \%$ \\
\hline Schering-Plough & United States & & & $\# 30$ & & & & & & & $11.11 \%$ \\
\hline Takeda Pharmaceutical & Japan & $\# 15$ & $\# 44$ & $\# 18$ & & & & - & & & $44.44 \%$ \\
\hline $\mathrm{UCB}$ & Belgium & & $\# 4$ & & & & & & & & $11.11 \%$ \\
\hline United Health Group & United States & & & $\# 10$ & & & & & & $\# 20$ & $22.22 \%$ \\
\hline Valeant Pharmaceuticals & Canada & & & & & & & & & $\# 78$ & $11.11 \%$ \\
\hline WellPoint & Canada & & & $\# 20$ & & & & & & & $11.11 \%$ \\
\hline Zimmer Biomet & United States & & & $\# 27$ & & & & & & & $11.11 \%$ \\
\hline
\end{tabular}




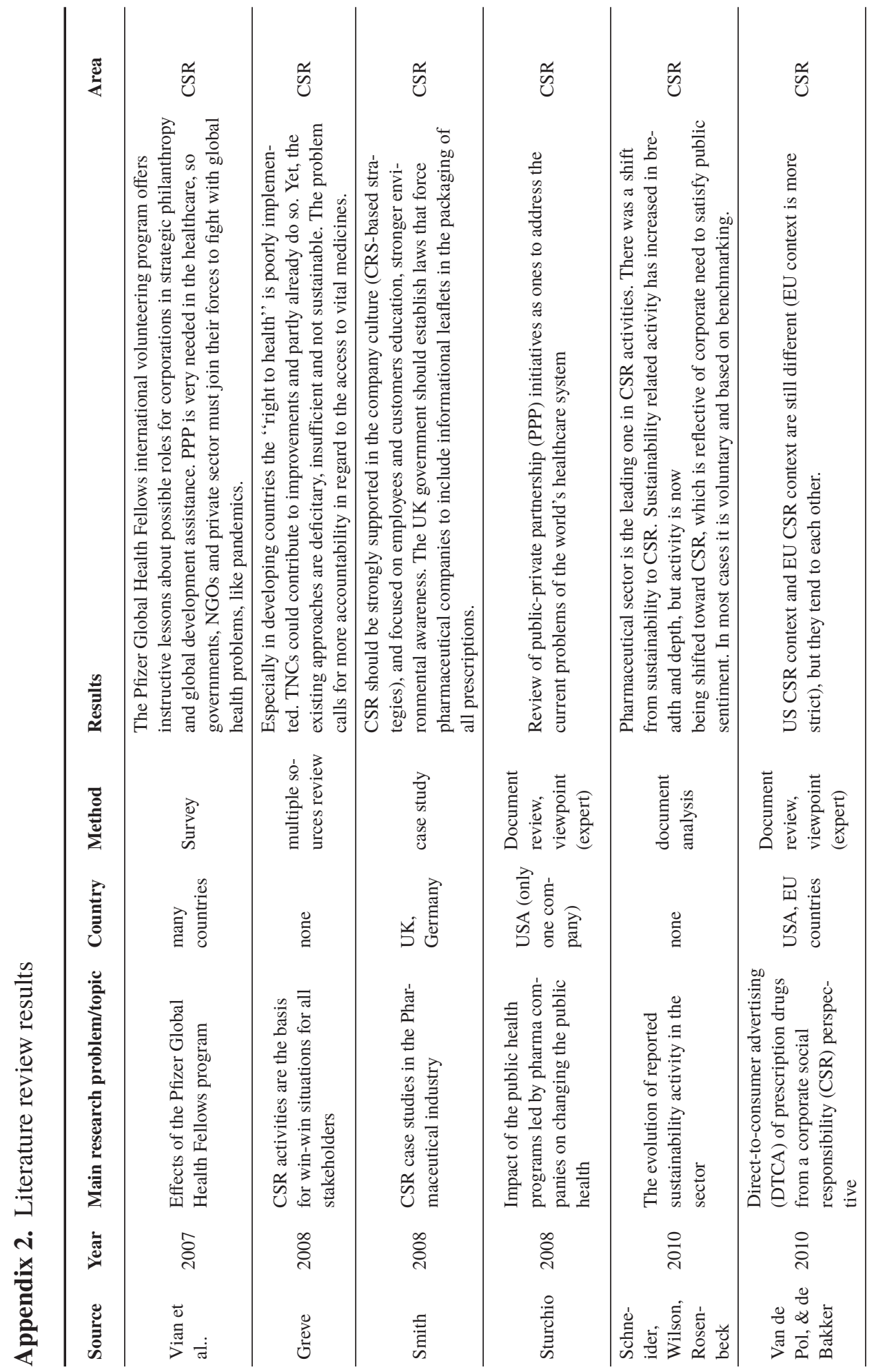




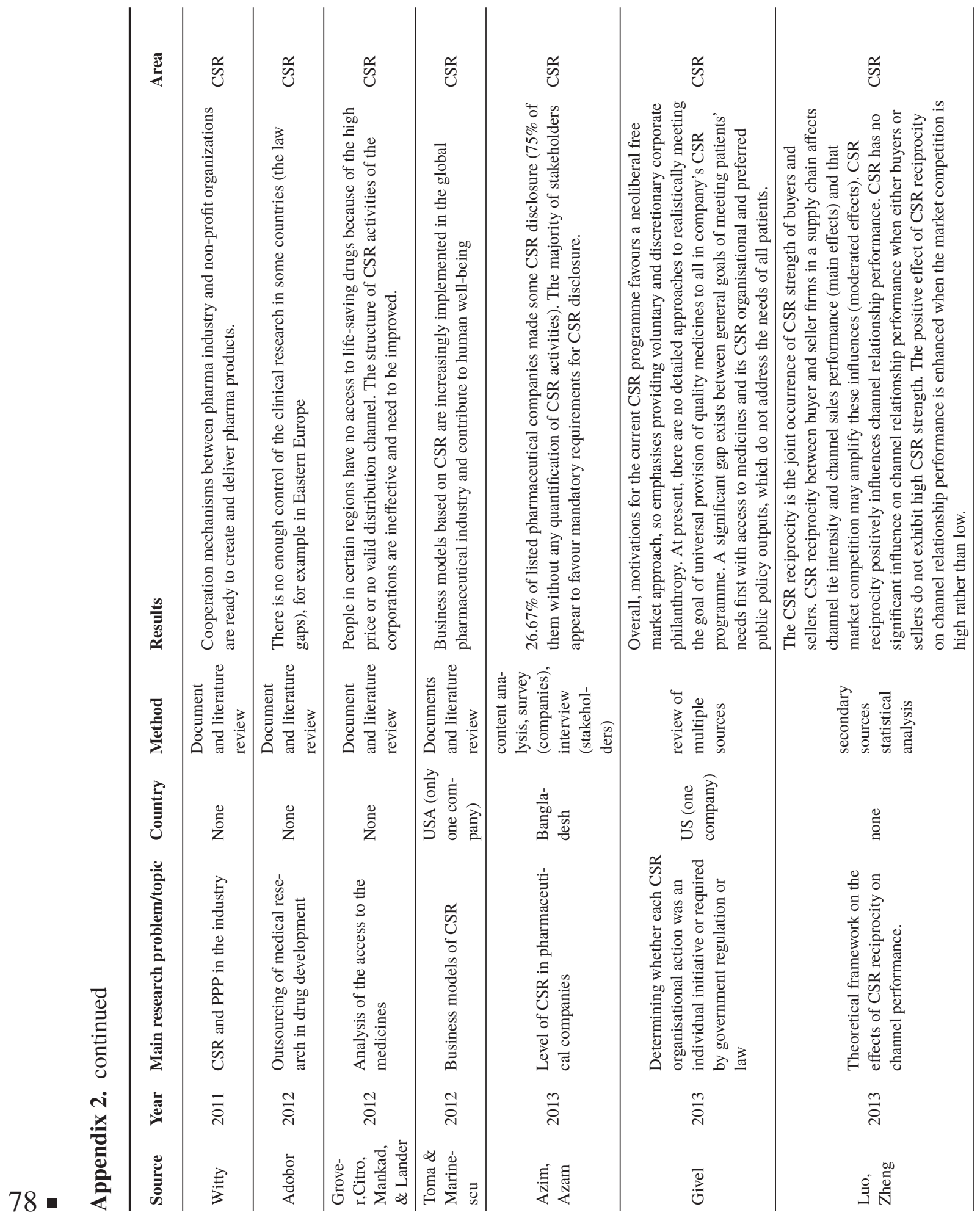




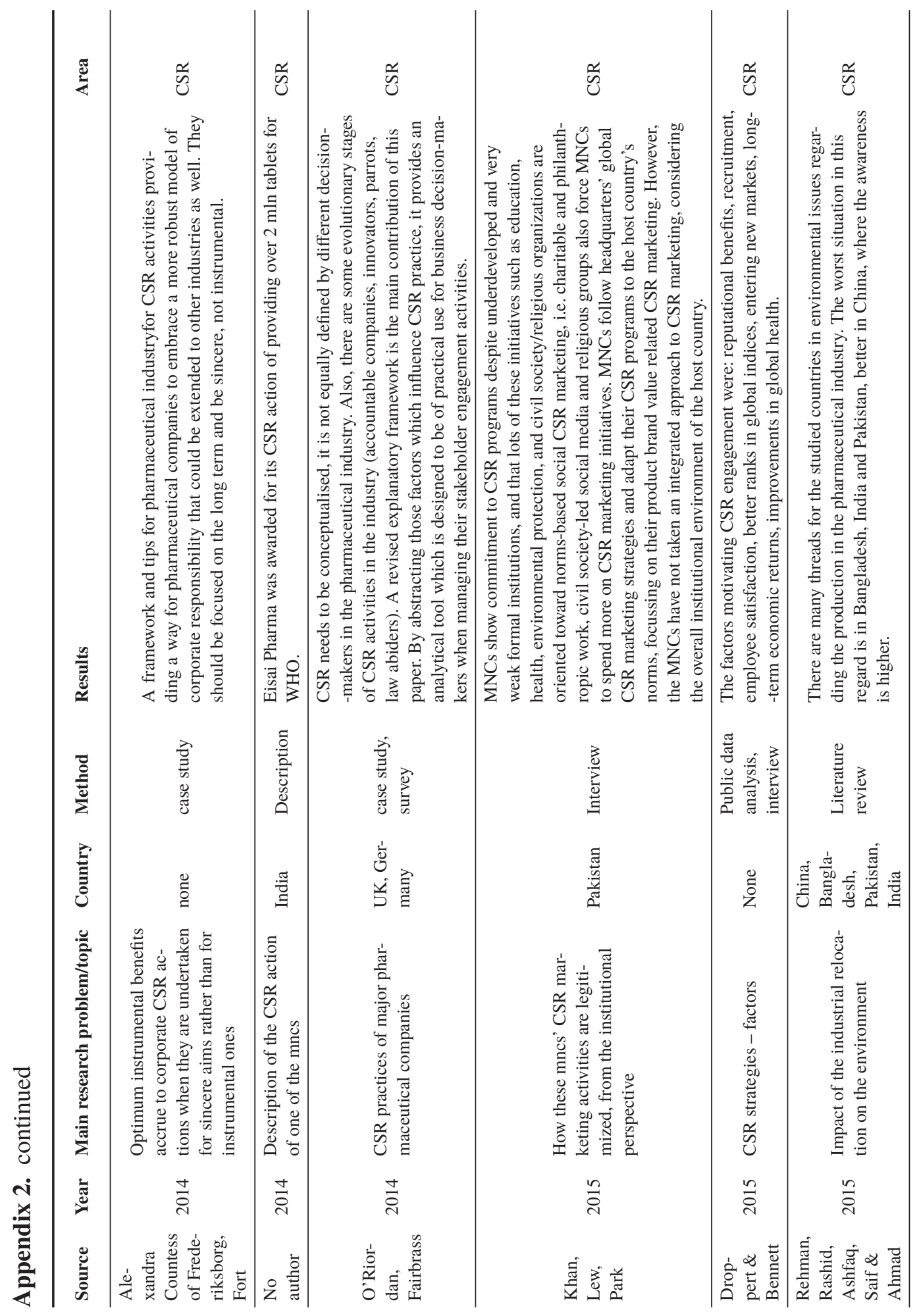

- 79 


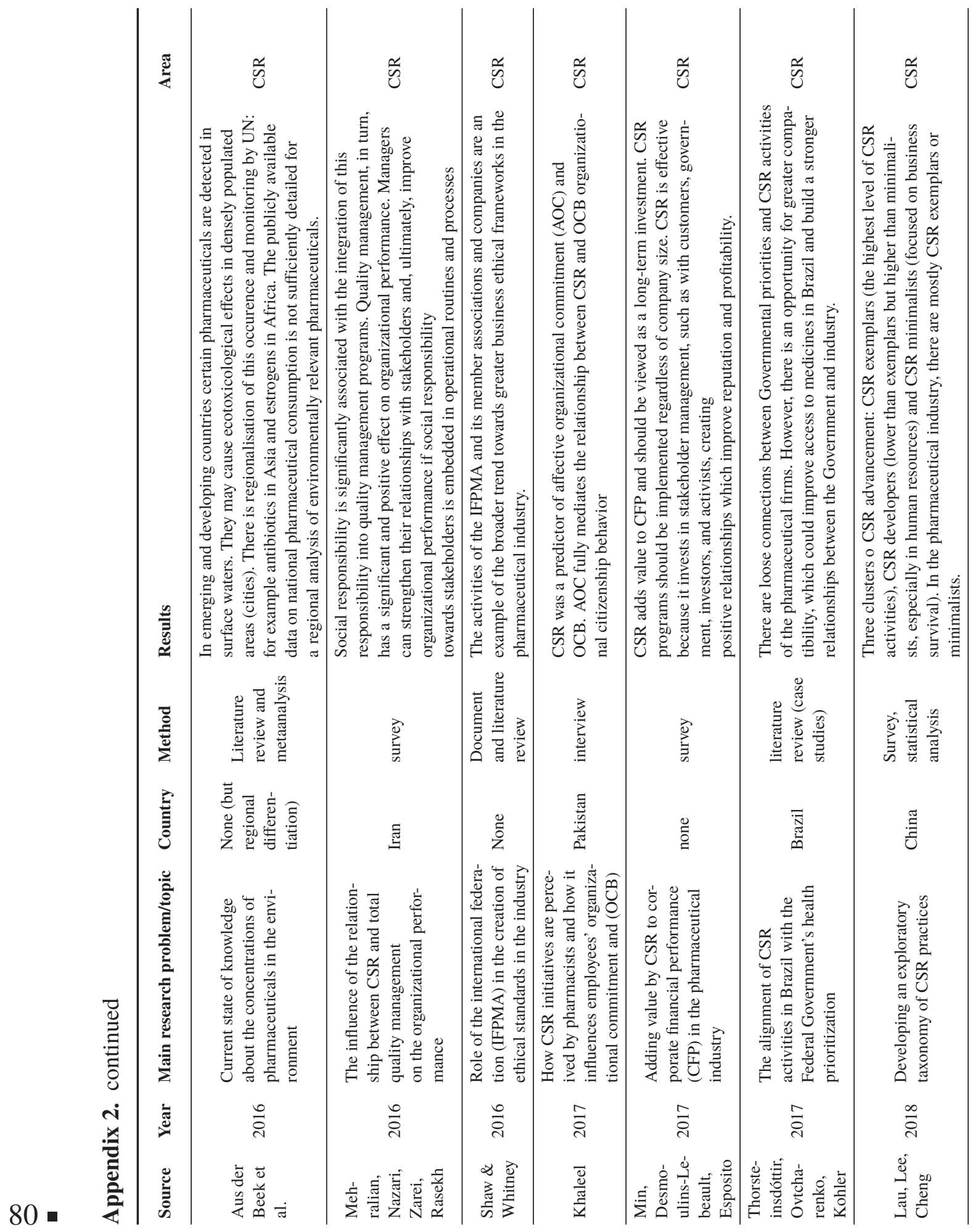




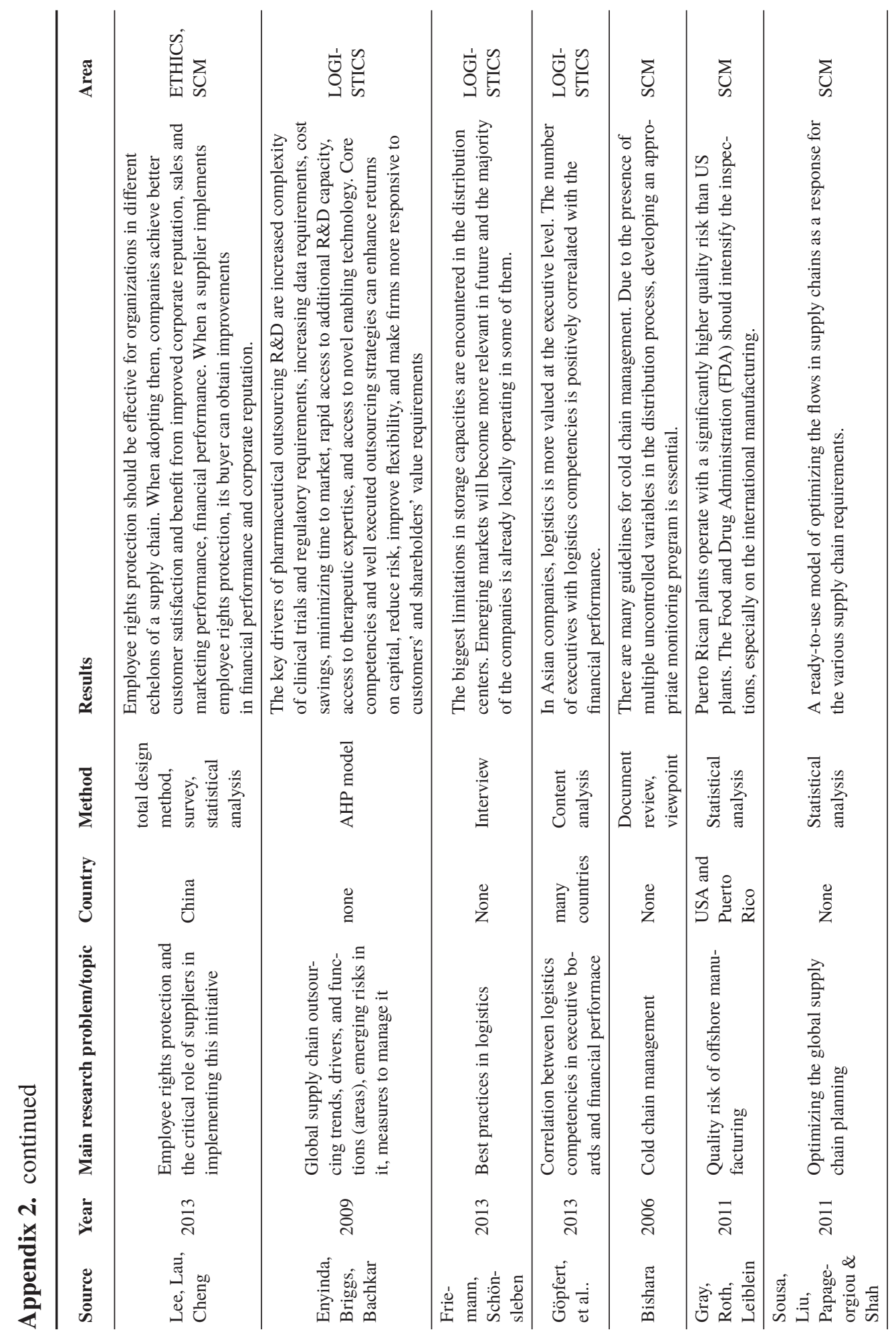

- 81 


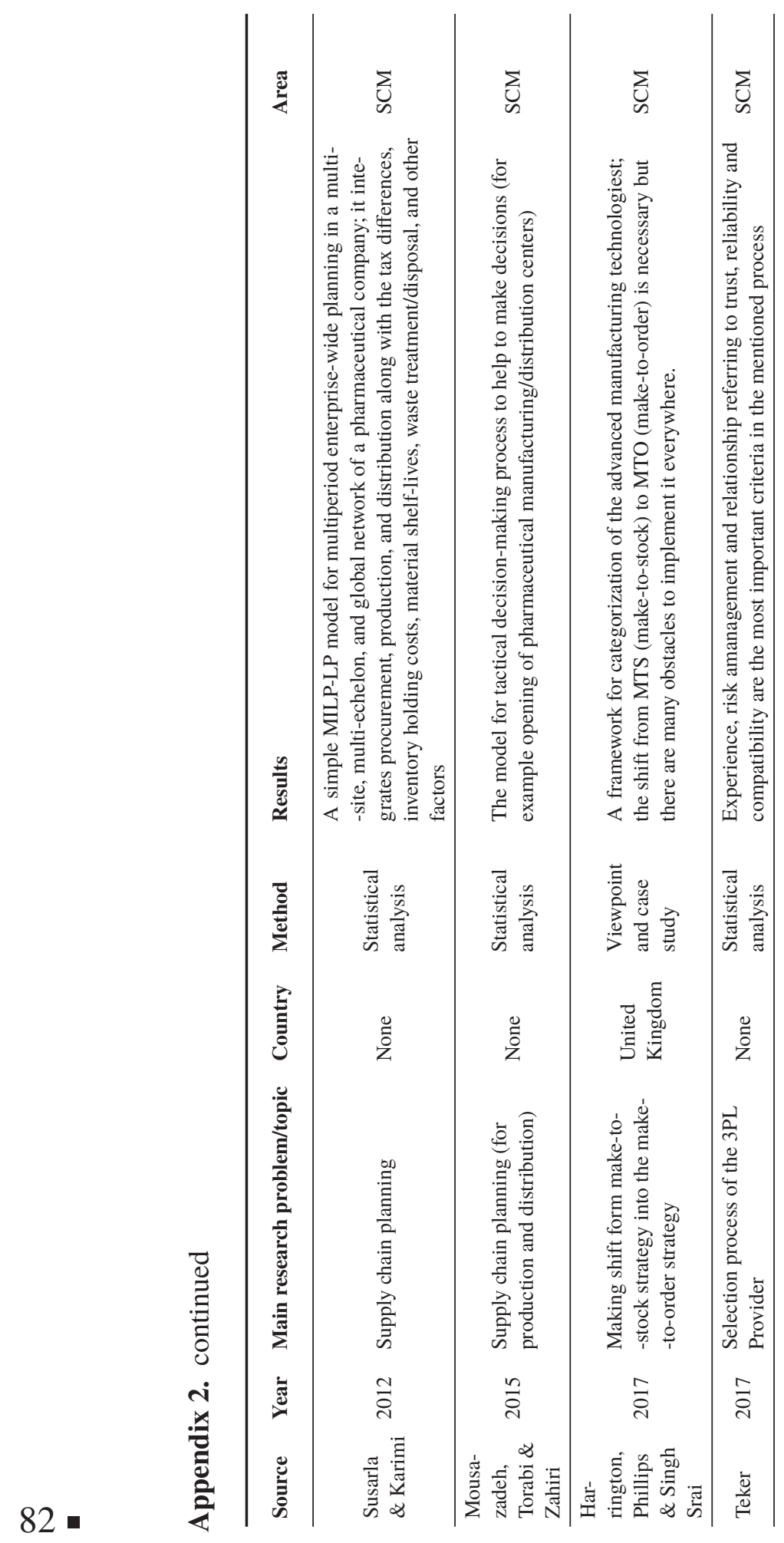

